\title{
Effect of Sulphur and Zinc on Rice Performance and Nutrient Dynamics in Plants and Soil of Indo Gangetic Plains
}

\author{
Anil Kumar Singh ${ }^{1}$, Manibhushan ${ }^{1}$, M. K. Meena ${ }^{1} \&$ Ashutosh Upadhyaya ${ }^{1}$ \\ ${ }^{1}$ Indian Council of Agricultural Research, Research Complex for Eastern Region, Patna, India \\ Correspondance: Anil Kumar Singh, Indian Council of Agricultural Research, Research Complex for Eastern \\ Region, Patna, India. E-mail: anil.icarpat@gmail.com
}

Received: August 20, 2012 Accepted: September 5, 2012 Online Published: October 12, 2012

doi:10.5539/jas.v4n11p162 URL: http://dx.doi.org/10.5539/jas.v4n11p162

\begin{abstract}
Rice is the staple food of more than three billion people in the world, most of who live in Asia.Rice is important crop of Indo Gangetic Plains of Bihar, productivity of system is stagnate and somewhere going down, to ascertain the role of sulphur and zinc an experiment was conducted at main campus of ICAR Research Complex of Eastern Region Patna with four levels of both nutrients i.e. sulphur and zinc, total 16 treatments were tested in Randomized Block Design. Both the nutrients were applied to rice and their direct and residual response was ascertained to rice and lentil in sequence. Based on three years of experimentation, results revealed that rice plant height is significantly affected by sulphur and zinc. Tallest plant $(101.7 \mathrm{~cm})$ was recorded at maturity with application $6 \mathrm{~kg} \mathrm{Zn}$ application $\mathrm{Zn}$. With the advance of stage dry matter accumulation was increased, it was not like the LAI which was decreased after Panicle initiation stage. Highest LAI (4.29) at anthesis was produced in the plots treated with $\mathrm{Zn}$ at $6 \mathrm{~kg} / \mathrm{ha}$. Dry matter share of root was in general less than $15 \%$ across the levels of sulphur and zinc during all the phenological stages. Maximum rice yield $(7.63 \mathrm{t} / \mathrm{ha})$ was recorded with combined application of $30 \mathrm{~kg}$ sulphur and $6 \mathrm{~kg}$ zinc, whereas corresponding minimum rice yield $(7.09 \mathrm{t} / \mathrm{ha}) \mathrm{was}$ recorded with absolute control plots where no application of zinc and sulphur was done during entire experimentation period.Maximum $(281.2 \mathrm{~kg} / \mathrm{ha})$ nitrogen uptake was recorded with $6 \mathrm{~kg}$ zinc treatment. However highest uptake of $\mathrm{P}(91.1 \mathrm{~kg} / \mathrm{ha})$ and $\mathrm{K}(150.4 \mathrm{~kg} / \mathrm{ha})$ was recorded in the plot supplemented with no $\mathrm{Zn}$ and sulphur at $40 \mathrm{~kg} / \mathrm{ha}$, respectively. Soil parameters viz., $\mathrm{pH}, \mathrm{EC}$ and organic carbon content did not influenced with the $\mathrm{S}$ and $\mathrm{Zn}$. N, $\mathrm{P}$, $\mathrm{K}, \mathrm{S}$ and Znwere affected significantly due to sulphur and zinc nutrition.
\end{abstract}

Keywords: dry matter assimilation, Indo Gangetic Plains, LAI, rice, sulphur, zinc

\section{Introduction}

Rice (OryzasativaL.) is widely grown in tropical and subtropical regions (Singh et al., 2012). It is staple food of not only Bihar but also for India and South Asia. According to IRRI, 2009, rice is the staple food of more than three billion people in the world, most of who live in Asia. It is important energy source of more than half of the world and $65 \%$ of the Indian population (Liu et al., 2008). Globally, rice is grown on 153Mha (FAO, 2006), though its production and consumption is concentrated in Asia, where more than $90 \%$ of all rice is consumed. India produces 103.41 million tons during 2011-12 from 44.07 million hectare with average productivity of $2270.75 \mathrm{~kg} / \mathrm{ha}$ (Singh et al., 2012). In Bihar, rice is cultivated on about 3.8 million hectare land but its productivity in this region is below the Indian national average. The low productivity of rice in India is attributed by several factors including balance nutrition. Balanced nutrition especially application of sulphur and zinc to the rice crop is one of the important inputs that can enhance productivity to a great extent. In Bihar, there is tendency to use indiscriminate amount of nitrogenous fertilizers and very limited amount of other nutrients' containing high analysis chemical fertilizers (Rahman et al., 2008). Rice and rice based cropping system have important role in the Eastern Indo Gangetic Plain to increase food production for a rapidly growing population. Due to intensification of cropand rapid adoption of improved cultivars has not only increased yield but also have significantly increased the output of nutrients and, where there has been an imbalance between outputs and inputs, has resulted in declining soil fertility and an increase in the incidence of deficiencies of certain plant nutrients, including sulphur and Zn.On an average to produce one tone of grain of high-yielding varieties of rice, remove about $22 \mathrm{~kg} \mathrm{~N}, 7 \mathrm{~kg} \mathrm{P}_{2} \mathrm{O}_{5}, 32 \mathrm{~kg} \mathrm{~K}_{2} \mathrm{O}, 5 \mathrm{~kg} \mathrm{MgO}, 4 \mathrm{~kg} \mathrm{CaO}, 1 \mathrm{~kg} \mathrm{~S}$ and $40 \mathrm{~g} \mathrm{Zn}$ from the soil (Chaudhary et al., 2007). 
Sulphur (S) is involved in amino acid and protein synthesis, enzymatic and metabolic activities in plants, which account for approximately $90 \%$ of organic $\mathrm{S}$ in the plant. Its deficiency is fast emerging in areas under oilseeds and pulses due to higher removal of S by crops (Singh \& Kumar, 2009). The sulphur requirement of rice varies according to the nitrogen supply. When $\mathrm{S}$ becomes limiting, addition of $\mathrm{N}$ does not change the yield or protein level of plants. Sulphur is required early in the growth of rice plants. If it is limiting during early growth, then tiller number and therefore final yield will be reduced (Blair \& Lefroy, 1987). Sulphur, however, is taken up by the roots of most plants in the oxidized sulphate form. It is unknown whether or not rice also can assimilate sulphide, but we suspect it is unlikely to be a major source of sulphur to the plant since rice is sensitive to low levels of sulphide in its tissues. Zinc is one of the most important micronutrient essential for plant growth especially for rice grown under submerged condition. Zinc deficiency continues to be one of the key factors in determining rice production in several parts of the country (Muthukumararaja \& Sriramachandrasekharan, 2012).Zn deficiency is the most widespread micronutrient disorder in lowland rice and application of $\mathrm{Zn}$ along with NPK fertilizer increases the grain yield dramatically in most cases (Fageria et al., 2011; Singh et al., 2011).Apart from major nutrients zinc is very much responsive to high intensive cereal based cropping system. Zinc is required in a large number of enzymes and plays an essential role in DNA transcription. To give impetus to the vegetative growth zinc plays a vital role especially under low temperature ambient and rhizosphere regime. Adequate availability of zinc to young and developing plants is certain promise for sufficient growth and development. To understand zinc their dynamic in soil plant system need to be ascertained. Its availability in soil is mainly governed by $\mathrm{pH}$ and $\mathrm{p}$ concentration. $\mathrm{Zn}$ translocation in the plant is also administrating by $\mathrm{P}: \mathrm{Zn}$ ration in the plant tissue, especially during seed development phase (Muthukumararaja \& Sriramachandrasekharan, 2012). Zinc role is as multifaceted as the interface that reduces its availability. Physiologically its role in a plant is either as a metal constituent in an enzymes or as a functional co-factor of number of enzymes reactions.In general zinc deficient plant show signs of low levels of auxins such as indole acetic acid (IAA). Zinc plays a greater role during reproductive phase especially during fertilization. Remarkably pollen grain contains zinc in very high quantity. At the time of fertilization most of zinc is diverted to seed only (Fageria et al., 2011). Reduction in yield of rice is often blamed to zinc sulphur deficiency. Zn deficiency is the most widespread micronutrient disorder in lowland rice and application of $\mathrm{Zn}$ along with NPK fertilizer increases the grain yield dramatically in most cases (Rahman et al., 2008; Chaudhary et al., 2007).

There is a need to ascertain and promote the uses of types of fertilizers required to correct the deficiency of all these nutrients especially sulphur and zinc. Keeping in the view of the importance of rice in the IGP and role of sulphur and zinc nutrient in their crop physiology and ultimately in the economic yield this experiment was undertaken. Indian farmers apply N, P and K fertilizers widely, it is found that application of micronutrient such as sulphur and zinc is not a usual practices. A marked higher incidence of micronutrient deficiency is found in crop due to intensive cropping, loss of fertile top soil and losses of nutrient through leaching (Rahman et al., 2008; Singh et al., 2011; Somani, 2008).

\section{Materials and Methods}

A field experiment was conducted at ICAR Research Complex for Eastern Region Patna during 2008-09 to 2010-11 in randomized block design (RBD) replicated with thrice to evolve suitable nutrient management system with respect to one secondary nutrient (sulphur) and one micro nutrient (zinc) in rice for Indo- Gangetic plains of Bihar. Total 16 treatment combination was tested i.e. four level of sulphur $S_{1}(0 \mathrm{~kg}), S_{2}(20 \mathrm{~kg}), S_{3}(30 \mathrm{~kg})$, and $\mathrm{S}_{4}(40 \mathrm{~kg})$ and zinc $\mathrm{Zn}_{1}(0 \mathrm{~kg}), \mathrm{Zn}_{2}(4 \mathrm{~kg}), \mathrm{Zn}_{3}(5 \mathrm{~kg})$ and $\mathrm{Zn}_{4}(6 \mathrm{~kg})$ were applied in combination, respectively, was applied on hectare basis. The experimental plot size was $10.0 \mathrm{~m} \mathrm{X} \mathrm{5.0} \mathrm{m.} \mathrm{21-25} \mathrm{days} \mathrm{old} \mathrm{seedlings} \mathrm{were}$ transplanted on $15^{\text {th }}$ July during each season. Transplanting was done keeping row to row distance of $25 \mathrm{~cm}$ and plant to plant $20 \mathrm{~cm}$ apart.Both sulphur and zinc applied as basal to rice crop and their direct effects on rice growth, development and performance was investigated. Various sources were used to supplement sulphur and zinc. Other nutrients especially NPK as well as all agronomic management practice were as pertherecommendedpractices for the region and were same for all the treatments. Since weather condition viz., rainfall, temperature (minimum and maximum). Relative humidity (\%) of the experimental site was with the normal range, consequent upon this o major incidence of pests and disease were noticed during all the three seasons of experimentations. Sulphur played a major role in the disease pests' management especially during the first season due to prolong rainy season and delayed onset of winter season.Dataon this account (diseases aspect) has not been presented in this paper, obviously due to having comparatively less relevance.The soil samples were collected as per the prescribed procedure at the onset of experiment and after the harvest of final crop. These soil samples analyzed following the procedure described by AOAC (1980) for physical and chemical parameter viz., $\mathrm{pH}, \mathrm{EC}\left(\mathrm{dSm} / \mathrm{M}^{-}{ }^{1}\right), \mathrm{OC}(\%)$, available $\mathrm{P}(\mathrm{kg} / \mathrm{ha})$ and available $\mathrm{K}(\mathrm{kg} / \mathrm{ha})$ before sowing and after harvest crop. 
At the time of the experimentation, texture of soil of experimental plot was siltyclay loam with mean $\mathrm{pH}$ value of 6.8 , electrical conductivity $0.17 \mathrm{ds} / \mathrm{m}$ in $1: 2$ soils: water solution, organic carbon 0.69 per cent, with available nitrogen $256.1 \mathrm{~kg} / \mathrm{ha}$, available phosphorus $29.1 \mathrm{~kg} / \mathrm{ha}$, exchangeable potash $197.1 \mathrm{~kg} / \mathrm{ha}$, sulphur $7.9 \mathrm{~kg} / \mathrm{ha}$ and zinc $0.78 \mathrm{~kg} / \mathrm{ha}$.

Biometrical data were recorded on growth, development, yield attributes and yield. Different parameters were recorded at different well defined physiological stages viz., tillering, panicle initiation stage (PI Stage), anthesis and maturity. These stages are critical stages for growth and development as well as realization of final output. Plant height $(\mathrm{cm})$, leaf area index (LAI), dry matter assimilation $(\mathrm{g} /$ hill), $(\%)$ dry matter translocation into shoot were observed and recorded during all the four stages. For recording of plant height 10 representative samples were earmarked and recorded at appropriate growth stages. LAI, dry matter assimilation, and dry matter translocation into shoot were measures on per hill basis. Random samples were collected for five hills, washed gently to remove the soil and other foreign materials. Fresh weight, total, shoot and root portion were taken first, then shot portion were further used to workout LAI. After recording of LAI, roots and shoots was separately pack in paper bags and oven dried till constant weight to know the total dry matter accumulation and translocation. Other parameters viz., panicle/ M2 grains/panicle were recorded by taking sample of one quadrate $\left(1.0 \mathrm{M}^{2}\right)$. Totalbiomass and grain yield were taken for whole plot basis and computed for $\mathrm{t} / \mathrm{ha}$. Harvest Index (\%), 1000-seed (g)was also recordedpost-harvest. Statistical analysis was carried out.Regular analysis of variance was performed for each traitfor all three seasons and the combined (Pooled) analysis over seasons after testing error variance homogeneity was carried out according to the procedure outlined by Gomez and Gomez (1984), using the MSTATC version 2.1 (Michigan State University, USA) statistical package design. Significant differences between the treatments were compared with the critical difference at $( \pm 5 \%)$ probability by LSD.

\section{Results}

Results obtained were now discussed under appropriate sub heads with suitable tables presented in proper format.

\subsection{Effects of Sulphur and Zinc on Rice Plant Height}

Rice plant height is one of the important growth and development indicators. Height was recorded during all the critical stages i.e.tillering, panicle initiation stage (PI stage), anthesis and maturity (Somani, 2008; Singh et al., 2011).Plant height of rice was significantly affected by both the nutrients (sulphur and zinc) during all the phonological stages; however the magnitude was not same forparticular levels and it was increases with the advancement of growth up to Anthesis and then after it was slow down considerably (Table 1) (Blair \&Lefroy, 1987).Application of sulphur at $20 \mathrm{~kg} /$ ha produced significantly taller plants over no application of sulphur $\left(\mathrm{S}_{1}\right)$ at all the growth stages. Application of sulphur at $30 \mathrm{~kg} / \mathrm{ha}$ showed superiority over $\mathrm{S}_{1}$ and $\mathrm{S}_{2}$ treatments but produces at par with highest level of sulphurapplication i.e. $40 \mathrm{~kg} / \mathrm{ha}$. At maturity, plots treated with sulphur at $40 \mathrm{~kg} / \mathrm{ha}$ produce taller plant $(97.3 \mathrm{~cm}$ ) (Rahmanet al., 2008; Singh et al.,2011). Similar type of response was also noticed in case of zinc application. Application of $\mathrm{Zn}$ at $5 \mathrm{~kg} / \mathrm{ha}$ recorded significantly higher plant height over no application of $\mathrm{Zn}$, however itproduces at par with $\mathrm{Zn}$ applied at $6 \mathrm{~kg} / \mathrm{ha}\left(\mathrm{Zn}_{4}\right.$ treatment) during entire life cycle. Maximum plant height $(101.7 \mathrm{~cm})$ at maturity was recorded with application $\mathrm{Zn}_{4}$, whereas corresponding minimum plant height $(78.5 \mathrm{~cm}$ ) was recorded with no application of $\mathrm{Zn}$ (Muthukumararaja \& Sriramachandrasekharan, 2012).

Table 1. Effect of sulphur and zinc nutrition on plant height $(\mathrm{cm})$ at different phenological stages

\begin{tabular}{ccccc}
\hline Treatments & Tillering & PI Stage & Anthesis & Maturity \\
\hline $\mathrm{S}_{1}(0 \mathrm{~kg})$ & 47.2 & 57.6 & 76.3 & 81.2 \\
$\mathrm{~S}_{2}(20 \mathrm{~kg})$ & 49.4 & 61.0 & 83.5 & 91.6 \\
$\mathrm{~S}_{3}(30 \mathrm{~kg})$ & 52.3 & 68.4 & 88.7 & 95.6 \\
$\mathrm{~S}_{4}(40 \mathrm{~kg})$ & 53.8 & 70.8 & 92.6 & 97.3 \\
$\mathrm{Zn}_{1}(0 \mathrm{~kg})$ & 49.8 & 59.1 & 73.1 & 78.5 \\
$\mathrm{Zn}_{2}(4 \mathrm{~kg})$ & 51.3 & 64.9 & 82.9 & 93.9 \\
$\mathrm{Zn}_{3}(5 \mathrm{~kg})$ & 53.9 & 69.8 & 91.6 & 98.4 \\
$\mathrm{Zn}(6 \mathrm{~kg})$ & 54.7 & 72.5 & 95.3 & 101.7 \\
$\mathrm{CD}( \pm 5 \%)$ & 1.9 & 4.3 & 5.7 & 5.1 \\
\hline
\end{tabular}

PI Stage: Panicle initiation stage. 


\subsection{Effects of Sulphur and Zinc on Rice Leaf Area Index (LAI)}

Sulphur application influences leaf area index (LAI) significantly. LAI was improved with advancement of growth stage till the anthesis. Marked reduction in LAI was noticed at maturity for both the tested nutrients. It was recorded that application of sulphur at $40 \mathrm{~kg} /$ ha produced highest LAI (4.27) at anthesis (Sahaa et al., 2007). Plots received $20 \mathrm{~kg}$ sulphur produces significantly higher LAI over no application and produced at par with other tested levels of sulphur in most of the phenological stages (Table 2). Marked response of graded doses of applied zinc on LAI was also noticed and it was more pronounce than sulphur treatments in general, though the highest was recorded with sulphur (Rahman et al., 2008; Singh et al., 2011).In case of zinc application highest LAI (4.19) was obtained with zinc at $6 \mathrm{~kg} / \mathrm{ha}$ and minimum (3.89) with no application of sulphur $\left(\mathrm{S}_{1}\right)$ at anthesis. However lower LAI was notice during tillering stage. Results showed that the treatment $\left(\mathrm{Zn}_{3}\right)$ consisting of zinc at $5 \mathrm{~kg} / \mathrm{ha}$ produced significantly higher LAI (4.13) over no application of zinc and at $4 \mathrm{~kg} / \mathrm{ha}$, however it produced at par with zinc applied at $6 \mathrm{~kg} / \mathrm{ha}$ (Charati \& Malakouti, 2006).

Table 2. Effect of sulphur and zinc nutrition on leaf area index (LAI) at different phenological stages

\begin{tabular}{ccccc}
\hline Treatments & Tillering & PI Stage & Anthesis & Maturity \\
\hline $\mathrm{S}_{1}(0 \mathrm{~kg})$ & 2.26 & 3.35 & 3.66 & 3.31 \\
$\mathrm{~S}_{2}(20 \mathrm{~kg})$ & 2.41 & 3.48 & 3.85 & 3.51 \\
$\mathrm{~S}_{3}(30 \mathrm{~kg})$ & 2.50 & 3.76 & 3.94 & 3.61 \\
$\mathrm{~S}_{4}(40 \mathrm{~kg})$ & 2.57 & 3.81 & 4.17 & 3.51 \\
$\mathrm{Zn}_{1}(0 \mathrm{~kg})$ & 2.27 & 3.51 & 3.89 & 3.17 \\
$\mathrm{Zn}_{2}(4 \mathrm{~kg})$ & 2.51 & 3.73 & 4.05 & 3.29 \\
$\mathrm{Zn}_{3}(5 \mathrm{~kg})$ & 2.60 & 3.91 & 4.13 & 3.56 \\
$\mathrm{Zn}_{4}(6 \mathrm{~kg})$ & 2.65 & 4.16 & 4.29 & 3.71 \\
$\mathrm{CD}( \pm 5 \%)$ & 0.13 & 0.17 & 0.21 & 0.15 \\
\hline
\end{tabular}

Note: PI Stage: Panicle initiation stage

\subsection{Effects of Sulphur and Zinc on Dry Matter Assimilation (G/Hill) in Rice}

Dry matter accumulation / assimilation are the important growth and development phenomenon which provide platform for realization of economic produce for any crop. To know the impact of sulphur and zinc on dry matter accumulation and at different phenological stages data were recorded and presented in Table 3. With the progression of stage dry matter accumulation was increased, it was not like the LAI which was decreased after Panicle initiation stage. Sulphur had significant effects on dry matter assimilation during all the phenological stages. Application of sulphur at $30 \mathrm{~kg}$ prove superior or at par with corresponding lower and higher dose , though the pattern of response was not similar for all thephenologicalstages.At maturity the range of response was limited and it was recorded minimum $(25.71 \mathrm{~g} / \mathrm{hill})$ to maximum $(27.65 \mathrm{~g} / \mathrm{hill})$. Similar types of results were also noticed by Charatiand Malakouti (2006). Role of zinc in growth and development is now well established fact, its interaction with sulphur is not much studies. In case of zinc it was noticed that highest $(28.25 \mathrm{~g} / \mathrm{hill})$ and lowest $(7.28 \mathrm{~g} / \mathrm{hill})$ dry matter was accumulated in case of $\mathrm{Zn}_{4}(6 \mathrm{~kg})$ and $\mathrm{Zn}_{1}(0 \mathrm{~kg}$ treatment at maturity and tillering respectively (Chaudhary et al., 2007; Muthukumararaja \& Sriramachandrasekharan, 2012).

Table 3. Effect of sulphur and zinc nutrition on dry matter assimilation ( $\mathrm{g} / \mathrm{hill}$ )

\begin{tabular}{ccccc}
\hline Treatments & Tillering & PI-Stage & Anthesis & Maturity \\
\hline $\mathrm{S}_{1}(0 \mathrm{~kg})$ & 7.57 & 18.41 & 22.19 & 25.71 \\
$\mathrm{~S}_{2}(20 \mathrm{~kg})$ & 7.89 & 18.77 & 23.41 & 26.77 \\
$\mathrm{~S}_{3}(30 \mathrm{~kg})$ & 8.21 & 19.98 & 25.17 & 27.16 \\
$\mathrm{~S}_{4}(40 \mathrm{~kg})$ & 8.27 & 20.18 & 26.23 & 27.65 \\
$\mathrm{Zn}_{1}(0 \mathrm{~kg})$ & 7.28 & 18.96 & 21.52 & 24.89 \\
$\mathrm{Zn}_{2}(4 \mathrm{~kg})$ & 7.69 & 19.77 & 22.54 & 25.52 \\
$\mathrm{Zn}_{3}(5 \mathrm{~kg})$ & 8.17 & 20.08 & 26.09 & 27.57 \\
$\mathrm{Zn}_{4}(6 \mathrm{~kg})$ & 8.54 & 20.73 & 24.02 & 28.25 \\
$\mathrm{CD}( \pm 5 \%)$ & 0.51 & 0.72 & 1.61 & 1.21 \\
\hline
\end{tabular}

Note: PI Stage: Panicle initiation stage 


\subsection{Effects of Sulphur and Zinc on (\%) Dry Matter Translocation into Shoot in Rice}

Dry matter production is wasteful process until it was directed to proper sink. Hence, to know the efficient sink to source relation, pattern of dry matter translocation during different phenological stages were studies. It was recorded that dry matter share of root was maximum at tillering and it was more than $15 \%$ across the levels of sulphur and zinc except at $\mathrm{S}_{1}(0 \mathrm{~kg})$ treatment where it was $20.9 \%$ (Table 4). Gradually diversion of photosynthate was more towards shoot and maximum at the time of maturity. At maturity minimum (86.7\%) and maximum (90.2) dry matter was translocate to shoot with $0 \mathrm{~kg}$ and $40 \mathrm{~kg}$ sulphur application (Singh et al., 2011). Across the phenological stage, anthesis was proved most crucial stage and a launching pad for realization of seed production, as it was evident from translocations of photosynthate, which was within a narrow range (86.4 to $88.1 \%$ ). Considerable variation was recorded at the time of maturity prove the importance of both the tested minerals rice production (Sahaa et al., 2007). Sulphur prove crucial when it matter most, maximum (90.2\%) was recorded with $40 \mathrm{~kg} \mathrm{~S}$ application, moreover, minimum (86.7\%) was noticed in case of plottreated with $0 \mathrm{~kg}$ sulphur (Sahaa et al., 2007; Rahman et al., 2008).

Table 4. Effect of sulphur and zinc nutrition on (\%) dry matter translocation into shoot

\begin{tabular}{ccccc}
\hline Treatments & Tillering & PI Stage & Anthesis & Maturity \\
\hline $\mathrm{S}_{1}(0 \mathrm{~kg})$ & 79.1 & 83.9 & 87.1 & 86.7 \\
$\mathrm{~S}_{2}(20 \mathrm{~kg})$ & 82.3 & 85.0 & 88.2 & 88.1 \\
$\mathrm{~S}_{3}(30 \mathrm{~kg})$ & 83.5 & 85.5 & 88.1 & 89.2 \\
$\mathrm{~S}_{4}(40 \mathrm{~kg})$ & 84.1 & 86.1 & 88.0 & 90.2 \\
$\mathrm{Zn}_{1}(0 \mathrm{~kg})$ & 77.9 & 83.9 & 86.4 & 87.9 \\
$\mathrm{Zn}_{2}(4 \mathrm{~kg})$ & 83.1 & 86.7 & 87.6 & 88.7 \\
$\mathrm{Zn}_{3}(5 \mathrm{~kg})$ & 84.2 & 86.6 & 87.4 & 89.6 \\
$\mathrm{Zn}_{4}(6 \mathrm{~kg})$ & 82.5 & 85.5 & 88.1 & 89.2 \\
$\mathrm{CD}( \pm 5 \%)$ & 0.41 & 1.07 & $\mathrm{NS}$ & 1.2 \\
\hline
\end{tabular}

Note: PI Stage: Panicle initiation stage

\subsection{Effects of Sulphur and Zinc on Yield Attributesand Yields in Rice}

Yield attributes were also influenced significantly with graded doses of sulphur and zinc. Number of panicle per square meter, which contributes to the economic yield, significantly influenced with both the nutrients. Maximum (311.4) and minimum (271.4) panicle/ $\mathrm{M}^{2}$ was recorded with the application of $\mathrm{Zn}$ at $6 \mathrm{kgand}$ with no application of sulphur (Table 1). Number of grainsper panicle was also influenced significantly with both the tested nutrients. Maximum (207.7) and minimum (191.8) grains per panicle, was recorded with $\mathrm{Zn}_{4}$ and $\mathrm{S}_{1}$ treatments respectively (Table 1). Total above ground biomass (t/ha) production was also varied due to graded application of sulphur and zinc. It was noticed that maximum (18.32) and minimum (17.12) above ground biomass was recorded with $\mathrm{Zn}_{4}$ and $\mathrm{S}_{1}$ treatment. Grain yield of rice was also affected significantly with the levels of both the factors/nutrients ( $\mathrm{S}$ and $\mathrm{Zn})$. Maximum (7.57 t/ha) and minimum $(7.20 \mathrm{t} / \mathrm{ha})$ grain yield was obtained with 6 and 0 kg/ha (Mondal et al., 2004; Sahaa et al., 2007; Singh et al., 1997).

In case of sulphur, application at $20 \mathrm{~kg} /$ ha produced rice grain $7.25 \mathrm{t} /$ ha significantly over control $\left(\mathrm{S}_{1}\right)$ however it produced significantly lower than other tested levels of i.e. $S_{3}(7.44 t / h a)$ and $S_{4}(7.51 t / h a)$.In case of zinc, application at $6 \mathrm{~kg} / \mathrm{ha}$ produced significantly higher grain yield $(7.61 \mathrm{t} / \mathrm{ha})$ over no zinc application, but produces at par with other tested levels of zinc(Table 5). Harvest index (HI) was not influenced significantly by any of tested factor, it might be due to characters highly influence with its genetic makeup, though the harvest index (HI) ranged in between 0.41 to 0.42 . Similar trend was also recorded in case of 1000 - grain weight and its range in between 15.9 to $16.1 \mathrm{~g}$ (Ali et al., 2012; Singh et al., 2002). 
Table 5. Effect of sulphur and zinc nutrition on yield attributes and yields of rice

\begin{tabular}{ccccccc}
\hline Treatments & $\begin{array}{c}\text { Panicle } \\
/ \mathrm{M}^{2}\end{array}$ & $\begin{array}{c}\text { Grains/ } \\
\text { panicle }\end{array}$ & Above Biomass (t/ha) & $\begin{array}{c}\text { Grain } \\
(\mathrm{t} / \mathrm{ha})\end{array}$ & $\begin{array}{c}\mathrm{HI} \\
(\%)\end{array}$ & 1000 seed (g) \\
\hline $\mathrm{S}_{1}(0 \mathrm{~kg})$ & 271.4 & 191.8 & 17.23 & 7.23 & 0.41 & 15.9 \\
$\mathrm{~S}_{2}(20 \mathrm{~kg})$ & 287.9 & 199.5 & 17.57 & 7.38 & 0.42 & 16.0 \\
$\mathrm{~S}_{3}(30 \mathrm{~kg})$ & 303.6 & 204.9 & 17.71 & 7.44 & 0.42 & 15.9 \\
$\mathrm{~S}_{4}(40 \mathrm{~kg})$ & 300.1 & 205.6 & 18.32 & 7.43 & 0.41 & 16.0 \\
$\mathrm{Zn}_{1}(0 \mathrm{~kg})$ & 274.0 & 193.1 & 17.12 & 7.19 & 0.42 & 15.9 \\
$\mathrm{Zn}_{2}(4 \mathrm{~kg})$ & 291.4 & 202.03 & 17.85 & 7.32 & 0.41 & 16.0 \\
$\mathrm{Zn}_{3}(5 \mathrm{~kg})$ & 307.9 & 205.59 & 17.74 & 7.45 & 0.42 & 16.0 \\
$\mathrm{Zn}_{4}(6 \mathrm{~kg})$ & 311.4 & 207.7 & 18.12 & 7.51 & 0.42 & 16.1 \\
$\mathrm{CD}( \pm 5 \%)$ & 15.6 & 9.08 & 0.31 & 0.12 & $\mathrm{NS}$ & $\mathrm{NS}$ \\
\hline
\end{tabular}

To get clear-cut response of both the factor on rice yield, combined two way data is presented in table 6 . Perusal of data revealed that minimum rice yield $(7.09 \mathrm{t} / \mathrm{ha})$ was recorded with absolute control plots where no application of zinc and sulphur was done during entire experimentation period. Whereas corresponding maximum (7.63 t/ha) rice yield was recorded with combined application of $30 \mathrm{~kg}$ sulphur and $6 \mathrm{~kg}$ zinc (Mondal et al., 2004; Singh et al., 2011). This combined analysis suggests that for better output and for balanced nutrition combined application is advocated.

Table 6. Effect of sulphur and zinc nutrition on rice seed yield $(\mathrm{kg} / \mathrm{ha})$ during 2010

\begin{tabular}{cccccc}
\hline Treatments & $\mathrm{S}_{1}(0 \mathrm{~kg})$ & $\mathrm{S}_{2}(20 \mathrm{~kg})$ & $\mathrm{S}_{3}(30 \mathrm{~kg})$ & $\mathrm{S}_{4}(40 \mathrm{~kg})$ & Mean of $\mathrm{Zn}$ \\
\hline $\mathrm{Zn}_{1}(0 \mathrm{~kg})$ & 7.09 & 7.17 & 7.23 & 7.27 & 7.19 \\
$\mathrm{Zn}_{2}(4 \mathrm{~kg})$ & 7.22 & 7.31 & 7.36 & 7.39 & 7.32 \\
$\mathrm{Zn}_{3}(5 \mathrm{~kg})$ & 7.29 & 7.46 & 7.52 & 7.53 & 7.45 \\
$\mathrm{Zn}_{4}(6 \mathrm{~kg})$ & 7.31 & 7.58 & 7.63 & 7.53 & 7.51 \\
Mean of S & 7.23 & 7.38 & 7.44 & 7.43 & \\
$\mathrm{CD}( \pm 5 \%)$ & Mean effects & 0.12 & \multicolumn{5}{c}{ Interaction 0.27} \\
\hline
\end{tabular}

\subsection{Effects of Sulphur and Zinc Nutrition Oncontentanduptake of NPK in Rice}

To know the effect of sulphur and zinc on NPK concentration (\%) and uptake ( $\mathrm{kg} / \mathrm{ha})$ in rice (whole plant) samples were analyses for above purpose. Data presented in Table 7, indicates that concentration and uptake of nitrogen, phosphorus and potassium due to application of sulphur and zinc, influenced significantly. Highest concentration (1.25 and 1.96 percent) of nitrogen in rice was recorded in plots fertilized with zinc $6 \mathrm{~kg}$. The lowest concentration (1.10 and 1.83 percent) of nitrogen was noticed in case of plots treated with $0 \mathrm{~kg}$ sulphur and $0 \mathrm{~kg}$ zinc. Likewise response was also obtained in case of phosphorus and potassium concentrations in both the crops. Highest $(0.57 \%)$ and lowest $(0.42 \%) \mathrm{P}$ concentration in rice recorded with $0 \mathrm{~kg}$ zinc application and $0 \mathrm{~kg}$ sulphur application. This is clear-cut indication of sulphur induce $\mathrm{P}$ deficiency and antagonistic relation of $\mathrm{P}$ and Zn (Chaudhary et al., 2007). K concentration inrice had been influenced by both the tested nutrients. Sulphur influenced rice greatly (Table 7). In general it was noticed that the concentration of Nwas higher side in due to Zn whereas a P \& K was recorded with S treatments (Singh et al., 2002; Sahaa et al., 2007). Uptake of NPK by rice and lentil is accordingly to the content and their above ground biomass they produced. Since biomass produced by the respective crops and contents of NPK are influenced significantly, similar trend was also repeated in case of uptake. In general maximum uptake of all three nutrients was recorded in case of rice (Table 7). Highest $\mathrm{N}$ uptake $281.2 \mathrm{~kg} / \mathrm{ha}$ was recorded with $6 \mathrm{~kg}$ zinc application, corresponding maximum uptake of $\mathrm{P}$ $(91.1 \mathrm{~kg} / \mathrm{ha})$ and $\mathrm{K}(150.4 \mathrm{~kg} / \mathrm{ha})$ was recorded in the plot supplemented with no $\mathrm{Zn}$ and sulphur at $40 \mathrm{~kg} / \mathrm{ha}$ (Ali et al., 2012; Sahaa et al., 2007). 
Table 7. Effect of sulphur and zinc nutrition on NPKconcentration (\%) uptake $(\mathrm{kg} / \mathrm{ha})$ in rice

\begin{tabular}{ccccccc}
\hline & \multicolumn{2}{c}{ Nitrogen } & \multicolumn{2}{c}{ Phosphorus } & \multicolumn{2}{c}{ Potash } \\
\cline { 2 - 7 } Treatments & Concentration (\%) & $\begin{array}{c}\text { Uptake } \\
(\mathrm{kg} / \mathrm{ha})\end{array}$ & Concentration (\%) & $\begin{array}{c}\text { Uptake } \\
(\mathrm{kg} / \mathrm{ha})\end{array}$ & Concentration (\%) & $\begin{array}{c}\text { Uptake } \\
(\mathrm{kg} / \mathrm{ha})\end{array}$ \\
\hline $\mathrm{S}_{1}(0 \mathrm{~kg})$ & 1.10 & 194.0 & 0.42 & 74.1 & 0.73 & 128.7 \\
$\mathrm{~S}_{2}(20 \mathrm{~kg})$ & 1.17 & 205.6 & 0.48 & 84.3 & 0.75 & 131.8 \\
$\mathrm{~S}_{3}(30 \mathrm{~kg})$ & 1.21 & 214.3 & 0.46 & 81.5 & 0.74 & 131.1 \\
$\mathrm{~S}_{4}(40 \mathrm{~kg})$ & 1.23 & 222.9 & 0.52 & 94.2 & 0.83 & 150.4 \\
$\mathrm{Zn}_{1}(0 \mathrm{~kg})$ & 1.09 & 190.0 & 0.57 & 97.6 & 0.78 & 133.5 \\
$\mathrm{Zn}_{2}(4 \mathrm{~kg})$ & 1.19 & 212.5 & 0.51 & 91.1 & 0.76 & 135.7 \\
$\mathrm{Zn}_{3}(5 \mathrm{~kg})$ & 1.23 & 218.2 & 0.48 & 85.1 & 0.78 & 138.4 \\
$\mathrm{Zn}_{4}(6 \mathrm{~kg})$ & 1.25 & 223.5 & 0.44 & 78.7 & 0.76 & 135.9 \\
$\mathrm{CD}( \pm 5 \%)$ & 0.08 & 11.7 & 0.05 & 6.7 & 0.03 & 13.1 \\
\hline
\end{tabular}

\subsection{Effects of Sulphur and Zinc Nutrition on Fertility Status of Soil}

Perusal of data presented in table 8 vindicate that the initial value of $\mathrm{pH}$ and $\mathrm{EC}$ was recorded normal, however organic carbon (\%) and $\mathrm{K}$ was in medium in category. Phosphorus is the only mineral which content was recorded and classified as high $(28.6 \mathrm{~kg} / \mathrm{ha})$. Sulphur and zinc content was recorded below bench mark level. After the end of three years crop cycle, $\mathrm{pH}$ and $\mathrm{EC}$ value were recorded normal. There are gradual build-up of organic carbon (\%), N, P and K due to application of sulphur and zinc; however significant build-up was noticed in case of sulphur and zinc content in the soil of experimental plots and it cross the critical limits and categorized as normal.This data show that every parameter was improved with the application of the minerals, this not only improving overall productivity of cropping system but also improving fertility status of soils as well (Ali et al., 2012; Sahaa et al., 2007; Soomani, 2008).

Table 8. Effect of sulphur and zinc nutrition on soil fertility status

\begin{tabular}{|c|c|c|c|c|c|c|c|c|}
\hline Treatments & $\mathrm{pH}$ & $\begin{array}{l}E C \\
d s / m\end{array}$ & $\begin{array}{l}\mathrm{OC} \\
(\%)\end{array}$ & $\begin{array}{l}\mathrm{N} \\
(\mathrm{kg} / \mathrm{ha})\end{array}$ & $\begin{array}{l}\text { P } \\
(\mathrm{kg} / \mathrm{ha})\end{array}$ & $\begin{array}{l}\mathrm{K} \\
(\mathrm{kg} / \mathrm{ha})\end{array}$ & $\begin{array}{l}S \\
(\mathrm{ppm})\end{array}$ & $\begin{array}{l}\mathrm{Zn} \\
(\mathrm{ppm})\end{array}$ \\
\hline Initial Value & 6.80 & 0.19 & 0.71 & 244.7 & 28.6 & 185.8 & 8.3 & 0.76 \\
\hline Status (I) & Normal & Normal & Medium & Low & High & Medium & Low & Low \\
\hline $\mathrm{S}_{1}(0 \mathrm{~kg})$ & 6.82 & 0.19 & 0.72 & 251.4 & 31.4 & 182.3 & 8.7 & 0.83 \\
\hline $\mathrm{S}_{2}(20 \mathrm{~kg})$ & 6.85 & 0.19 & 0.72 & 257.3 & 33.1 & 190.6 & 9.1 & 0.87 \\
\hline $\mathrm{S}_{3}(30 \mathrm{~kg})$ & 6.91 & 0.20 & 0.73 & 268.9 & 30.1 & 193.7 & 9.5 & 0.92 \\
\hline $\mathrm{S}_{4}(40 \mathrm{~kg})$ & 6.95 & 0.20 & 0.74 & 286.5 & 27.3 & 189.9 & 8.8 & 0.94 \\
\hline $\mathrm{Zn}_{1}(0 \mathrm{~kg})$ & 6.86 & 0.18 & 0.70 & 242.9 & 28.5 & 183.4 & 8.7 & 0.82 \\
\hline $\mathrm{Zn}_{2}(4 \mathrm{~kg})$ & 6.84 & 0.19 & 0.71 & 254.3 & 30.7 & 185.9 & 8.6 & 0.91 \\
\hline $\mathrm{Zn}_{3}(5 \mathrm{~kg})$ & 6.84 & 0.19 & 0.74 & 271.4 & 32.9 & 187.3 & 8.6 & 0.96 \\
\hline $\mathrm{Zn}_{4}(6 \mathrm{~kg})$ & 6.83 & 0.20 & 0.76 & 289.4 & 34.2 & 193.2 & 1.1 & 0.98 \\
\hline Status (F) & Normal & Normal & Medium & Low & High & Medium & Normal & Normal \\
\hline $\mathrm{CD}( \pm 5 \%)$ & NS & NS & NS & 27.6 & 2.6 & NS & 0.6 & 0.07 \\
\hline
\end{tabular}

\section{Discussions}

Rice responses to added minerals i.e. sulphur and zinc were observed and recorded during all the growth and development stages. Stature of plant leads to structure and capacity to capture sun light to assimilate photosynthate by virtues of more leaves. As a plant grows taller there are better possibilities to have more 
number of effective's leaves. Sulphur and zinc are known for precursor of growth as they play greater and crucial role during early phase of plant life. Zinc role is as multifaceted as the interface that reduces its availability.Physiologically its role in a plant is either as a metal constituent in an enzymes or as a functional co-factor of number of enzymes reactions.In general zinc deficient plant show signs of low levels of auxins such as indole acetic acid (IAA). Investigation gives sound footing that zinc is required for synthesis of tryptophan, which in turn is precursor for synthesis of IAA (Ali et al., 2012; Somani, 2008; Chaudharyet al., 2007). Obviously due to the reason narrated above all the growthanddevelopmentindices understudies was marked better with zinc treatment as compared to its companion sulphur. Tallest plants $(101.7 \mathrm{~cm})$ at maturity was recorded with maximum $\mathrm{Zn}$ doses $(6 \mathrm{~kg} / \mathrm{ha})$, interestinglycorresponding minimum plant height $(78.5 \mathrm{~cm})$ was noticesin case of no application of Zn, clearly demonstrated the role of Znand its marked influenced on plant height. In case of sulphur application at $30 \mathrm{~kg} / \mathrm{ha}$ and above has marked effect on plant height. Though there was no definite trend was noticed this might be due temperature gradient and their reaction with soil clay complex under reduced rhizospher environment. At maturity, sulphur application at $40 \mathrm{~kg} / \mathrm{ha}$ produce taller plant $(97.3 \mathrm{~cm})$ Alike responses were also noticed in case of LAI, dry matter assimilation and translocation to above ground parts (shoots) and below ground parts (roots). Maximum LAI (4.29) was noticed at anthesis stage with $5 \mathrm{~kg} \mathrm{Zn}$ application. PI Stage is onset of reproductive stage with full of green foliage, during this stage accelerated assimilation of photosynthate is utmost required, hence, LAI were notice highest at PI stages at all the level of sulphur and zinc as compare to other stages. At maturity due to falling of older leaves decreased LAI were noticed. Dry matter production were increased with advancement of stages till maturity though the rate were decreased after anthesis obviously due to less assimilation of photosynthate because of less leaf area is available to photosynthesis activities. These parameter/traits are directly related to growth and developments, existence of apical dominance phenomenon were also noticed. Since zinc is precursor of tryptophan which is supposed to plays decisive role in synthesis to auxins, the main factor behind apical dominance, growth and development. Sulphur plays a greater role in development and guards against the attack of disease (Sahaaet al., 2007; Charati; Malakouti, 2006). Dry matter translocations to shoot and root were not static, with advancement of life cycle, share of shoots increases till maturity. Sulphur played crucial role in diversion of photosynthate towards the shoot at every growth stages and marked variation was noticed at PI and maturity stages. It indicate role of sulphur is much more in signaling process of photosynthate especially after onset of reproductive stages (Rahamn et al., 2008; Charati \& Malakouti, 2006). Maximum 90.2\% diversion of assimilation towards shoot portion was noticed in the plots treated with $40 \mathrm{~kg}$ sulphur at maturity.

After anthesis (flowering), high concentration of zinc in plant will enhance cell differentiation. Zinc plays a greater role during reproductive phase especially during fertilization. Remarkably pollen grain contains zinc in very high quantity. At the time of fertilization most of zinc is diverted to seed only (Singh et al., 2011). Due to this reason all the yield attributing traits were either recorder equal or higher over sulphur treatments. Highest Panicle $/ \mathrm{M}^{2}(311.4)$ with $\mathrm{Zn}$ applied at $6 \mathrm{~kg} / \mathrm{ha}$. However in case above ground biomass, maximum (18.32t/ha) was recorded in the plots treated with sulphur at $40 \mathrm{~kg} / \mathrm{ha}$. Interaction effects of sulphur and zinc was significant at $5 \%$ level and two way tables (Table 6) were presented especially for this trait only.Combined application of $\mathrm{S}$ and $\mathrm{Zn}$ are capable of doing phenomenon and was proven for most important and economic traits and highest $(7.63 \mathrm{t} / \mathrm{ha}$ ) was recorded in plots treated with $30 \mathrm{~kg} \mathrm{~s}$ and $6 \mathrm{~kg} \mathrm{Zn}$ (Chaudhary et al., 2007; Charati \& Malakouti, 2006). Marked variations were also recorded concentration and uptake of nitrogen, phosphorus and potassium by plants at maturity. Uptake is nothing but biomass multiply by its concentration (\%). Sulphur and Zinc had significant influenced on concentration and uptake as they plays important role in growth and development. Both nutrients plays identical role in case of nitrogen content and uptake, However, zinc take negative leads in case of phosphorus, moreover, sulphur plays vital role in potassium content and uptake zinc seems to be neutral. This is because of $\mathrm{Zn}$ and sulphur had equal role in nitrogen metabolism. Phosphorus content in plants in general were more especially in seeds as compare to other phenological stages. $\mathrm{Zn}$ and phosphorus has antagonistic relation with each other, which is clearly vindicated by the results of this experimentation (Muthukumararaja \& Sriramachandrasekharan,2012). Sulphur and zinc nutrition failed to influence on soil parameters viz., $\mathrm{pH}, \mathrm{EC}$ and organic carbon content, however, other nutrient viz., N, P, K, S and Znwere affected significantly. Slightly improvement was notice in case of NPK buildup. Significant buildups in the soils were notice in case of sulphur and zinc which was initially low, become sufficient due to continuous addition to the soil. Improvement in fertility status leads to improvement in productivity status of the experimental plot (Sahaa et al., 2007; Muthukumararaja \& Sriramachandrasekharan, 2012; Singh et al., 2011).

\section{References}

Ali, R. I., Awan, T. H. Ahmad, M., Saleem, M. U., \& Akhtar, M. (2012). Diversification of Rice-Based Cropping 
Systems to Improve Soil fertility, Sustainable Productivity and Economics. J. Animal \& Plant Sciences., 22, 108-112.

Blair, G. J., \& Lefroy, R. D. B. (1987). Sulphur cycling in tropical soils and the agronomic impact of increasing use of S free fertilizers, increased crop productionand burning of crop residue. In: Proceedings of the Symposium on Fertilizer Sulphur Requirements and Sources in Developing Countries of Asia and the Pacific (pp. 12-17). FADI- NAP, FAO, TSI and ACIAR Bangkok, Thailand,

Charati, A., \& Malakouti, M. J. (2006). Effect of zinc and cadmium concentrations on the rates of their absorption by rice and on some growth characteristics of the plant (Oryza sativa L.) part 2: yield and composition. 18th world congress of soil science (pp: 155-173).Philadelphia, Pennsylvania, July 9-15, 2006, USA.

Chaudhary, S. K., Thakur, S. K., \& Pandey, A. K. (2007). Response of wetland rice to nitrogen and zinc. Oryza, 44(1), 31-34.

Fageria, N. K., Dos Santos, A. B., \& Cobucci, T. (2011). Zinc nutrition of lowland rice. Comm. Soil Sci. Plant Anal., 42, 1719-1727. http://dx.doi.org/10.1080/00103624.2011.584591

Food and Agricultural Organization (FAO). (2006). Retrieved from: http// www.fao.org

Gomez, K. A., \& Gomez, A. A. (1984). Statistical procedures for agricultural research. John Wiley \& Sons Inc., Singapore, 2nd Edn.

IRRI (International Rice Research Institute). (2009). Rough rice production by country and geographical region-USDA. Trend in the rice economyIn: world rice statistics. Retrieved from: www.irri.org/science/ricestat

Liu, G., Bernhardt, L., Jia, H., Wamishe, A., \& Jia, Y. (2008). Molecular characterization of the recombinant inbred line population derived from a Japonica-Indica rice cross. Euphytica, 159, 73-82. http://dx.doi.org/10.1007/s10681-007-9459-6

Mondal, S. S., Arup, G., Debabrata, A., \& Maiti, D. (2004). Production potential and economics of different rainfed rice (Oryzasativa) - based utera cropping systems and its effect on fertility buildup of soil. Indian Journal of Agronomy, 49, 6-9.

Muthukumararaja, T. M., \& Sriramachandrasekharan, M. V. (2012). Effect of zinc on yield, zinc nutrition and zinc use efficiency of lowland rice. Journal of Agril. Tech., 8, 551-561.

Rahman, M. T., Jahiruddin, M., Humauan, M. R., Alam, M. J., \& Khan, A. A. (2008). Effect of Sulphur and Zinc on Growth, Yield and Nutrient Uptake of Boro Rice (Cv. BrriDhan 29) . J. Soil. Nature., 2, 10-15.

Sahaa, P. K., Ishaqueb, M., Salequeb, M. A., Miahb, M. A. M., Panaullahb, G. M., \& Bhuiyanb N. I. (2007). Long-Term Integrated Nutrient Management for Rice-Based Cropping Pattern: Effect on Growth, Yield, Nutrient Uptake, Nutrient Balance Sheet, and Soil Fertility Communications in Soil Science and Plant Analysis, 38(5-6), 579-610.

Singh, A. K., \& Kumar, P. (2009). Nutrient management in rainfed dryland agro ecosystem in the impending climate change scenario. Agril. Situ. India, LXVI(5), 265-270.

Singh, A. K., Chandra, N., \& Bharati, R. C. (2012). Effects genotypes and planting time on phenology and performance of rice (Oryzasativa L.). Vegetos, 25, 151-156.

Singh, A. K., Meena, M. K., \& Bharati, R. C. (2011). Sulphur and Zinc Nutrient Management in rice-lentil cropping system. International Conference on "Life Science Research for Rural and Agricultural Development” (pp 66-67). 27-29 December, 2011, CPRS Patna (Bihar).

Singh, S. K., Varma, S. C., \& Singh, R. P. (2002). Integrated Nutrient Management in Rice and its Residual Effect on Lentil. Indian J. Agric. Res., 36(4), 286-289.

Somani, L. L. (2008). Micronutrients for Soil and Plant Health (pp.14-74). Agrotech Publishing Academy. 